\title{
Growth performance and carcass characteristics of Awassi, Morkaraman and Tushin lambs grazed on pasture and supplemented with concentrate
}

\author{
M. Macit, N. Esenbuga and M. Karaoglu \\ Department of Animal Science, Atatürk University, College of Agriculture \\ 25240, Erzurum, Turkey
}

(Received 6 August 2001; accepted 31 January 2002)

ABSTRACT

Growth performance $(n=158)$ and carcass characteristics of 5 Awassi (A), 5 Morkaraman (M) and 4 Tushin (T) lambs weaned at 2.5 months of age were evaluated. The lambs were fed a concentrate mixture and allowed to graze for 70 days. At the end of the 70-day grazing period, $M$ lambs showed the highest daily weight gain and the amount of concentrate consumed per body weight gain. The effects of breed and sex of lamb on daily weight gain on pasture were significant $(\mathrm{P}<0.05)$ and highly significant $(\mathrm{P}<0.01$ ), respectively. Male lambs were superior to female lambs with respect to daily weight gain. Slaughter traits and carcass characteristics of 14 male lambs representing three fat-tailed breeds were compared at the end of the grazing period of the ycar in which they were born. I Iot carcass weight and hindshank weight of $M$ lambs were heavier than those of $A$ and $T$ lambs. $M$ had higher hot dressing percentage and larger $M$. longissimus dorsi (LD) area than those of $A$ and $T$ lambs. Most of the weights of wholesale cuts were significantly $(\mathrm{P}<0.05 ; \mathrm{P}<0.01)$ affected by brecd. It is recommended that either $\mathrm{A}, \mathrm{M}$ and $\mathrm{T}$ male and female lambs weaned at 2.5 months of age in eastern Turkey should be fed with $450 \mathrm{~g}$ concentrate per head per day on pasture for 3 to 3.5 months of grazing season, or lambs should be supplemented with more than $450 \mathrm{~g}$ concentrate feed on pasture because native fat-tailed breeds supplemented with $450 \mathrm{~g}$ concentrate on pasture did not give carcasses with an adequate commercial weight in the 70-day fattening period.

KEY WORDS: fat-tailed lambs, growth, semi-intensive conditions, carcass characteristics

\section{INTRODUCTION}

Approximately $87 \%$ of Turkey's sheep population (30.3 million heads) consists of fat-tailed breeds. Sheep meat (116.000 tons) is an important contribution (22.5\%) to red meat production in Turkey (Anonymous, 1997). On the other hand present 
meat production performances of native slieep breeds are far from meeting requirement (Bicer et al., 1992).

One of the factors affecting economical sheep meat production is higher growth and feed conversion efficiency of the material used. There are two alternatives for genetic improvement of lamb slaughter production with native sheep breeds. The first is pure breeding of indigenous breed; the second is crossbreeding with a mutton type sire breed to obtain maximum profit (Guney and Bicer, 1986).

Some studies on slaughter lamb production under intensive feeding conditions in Turkey have been performed (Guney and Bicer, 1986; Elicin et al., 1989a, b; Macit et al., 1997). Growth performance, slaughter and carcass characteristics of the indigenous breeds of eastern Turkey were studied by Baytndtr (1980), Geliyi and Ilaslan (1984) and Aksoy (1994). Such information is essential in planning breeding programs to improve the amount of meat production and quality characteristics of carcasses of indigenous Turkish breeds.

The objective of this study is to evaluate growth performance, slaughter characteristics and carcass characteristics of several pure breeds raised under semiintensive management.

\section{MATERIAL AND METHODS}

The experiment was conducted at the Research and Application Farm of the College of Agriculture, Atatürk University, Erzurum, and involved 158 fat-tailed Awassi $(\mathrm{A}=94)$, Morkaraman $(\mathrm{M}=52)$ and Tushin $(\mathrm{T}=12)$ male and female lambs used to determine growth performance of fat-tailed breeds. The lambs were born in March 1998 and kept with their dams until approximately 2.5 months of age. At weaning they were weighed then divided into three treatment groups and subjected to semi-intensive feeding management. The concentrate mixture consisted of $(\%)$ : barley, 42 ; maize, 24 ; soyabean meal, 10 ; wheat bran, 4 ; molasses, 8; limestone, 3; sunflower meal, 8; salt, 0.9 ; premix, 0.1 . The concentrate had $88 \%$ DM, $16 \%$ crude protein (CP), $10 \%$ crude fat (CF) and $2500 \mathrm{Kcal} \mathrm{ME} \mathrm{per}$ $\mathrm{kg}$. Average daily ration of concentrate was $450 \mathrm{~g}$ as to feed basis per lamb during the grazing period on pasture. Primary forage plants of pasture were Festuca ovina, Koleleria cristata, Bromus tomentalus, Medicago sp., and Onobrychis $\mathrm{sp}$. The concentrate was fed to the lambs in the evening in an open-shed barn to house them during the night.

The concentrate consumption in addition to grazing on pasture and the liveweight of lambs were recorded biweekly. At the end of the 70-day fattening period, $5 \mathrm{~A}$ and $5 \mathrm{M}$, and $4 \mathrm{~T}$ male lambs whose weights were closest to the average final weight of male lambs were slaughtered for subsequent carcass analysis. 
After slaughter, head, skin, feet and offal were removed and weighed. The carcasses were chilled at $+4^{\circ} \mathrm{C}$ for $24 \mathrm{~h}$ before jointing and measurements taken on the intact cold carcass (Kempster et al., 1982). The fat tail was removed from each carcass prior to cutting into wholesale cuts (Figure 1) according to American Standards (Anonymous, 1973). The wholesale cuts including fat tail were weighed and recorded. Measurements included fat thickness over the $M$. longissimus dorsi (LD), quantity of kidney and pelvic fat and LD area.

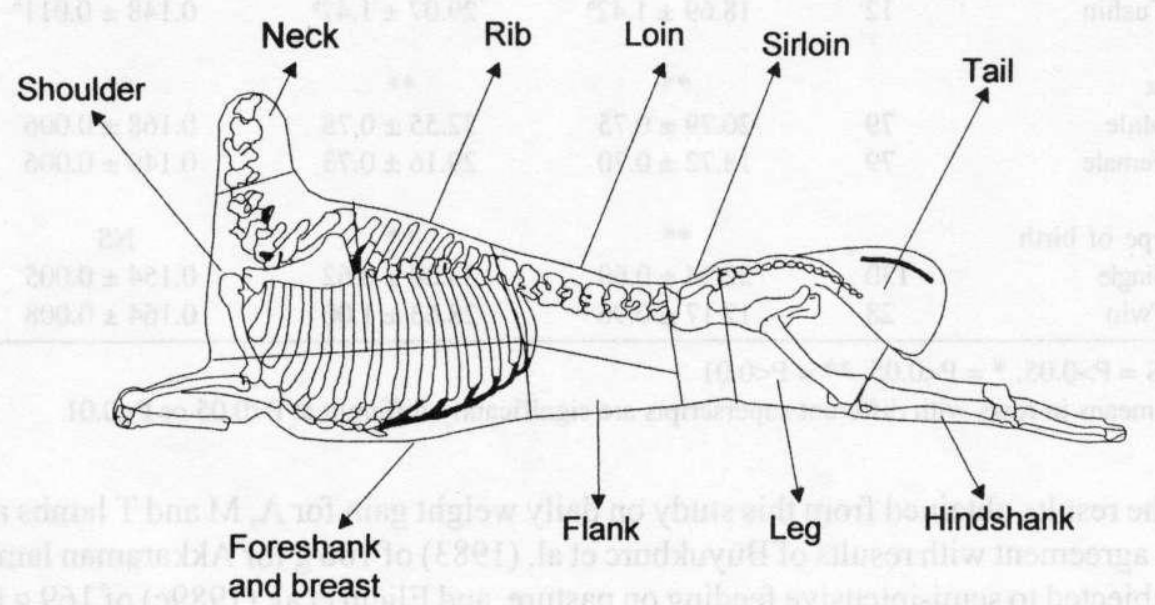

Figure 1. Wholesale cuts of lamb carcass

The statistical analysis was conducted using the GLM procedure of SAS (1985). The data on growth performance were analyzed by a mathematical model which included the effects of breed (A, M, T), sex and type of birth (single and twin) of the lambs. Not all of the interactions investigated in this study were included in the model because they were non-significant. Significant differences between means with respect to growth performance were tested using Duncan's multiple range tests (Duncan, 1955). The data concerning the non-carcass components and carcass characteristics were analyzed by another linear model including only the effect of breed.

\section{RESULTS AND DISCUSSION}

Daily weight gain and concentrate intake per $\mathrm{kg}$ weight gain on pasture

The effect of breed on daily weight gain (Table 1) was significant $(\mathrm{P}<0.05)$; the difference between $\mathrm{M}$ and $\mathrm{T}$ lamb groups was found to be significant $(\mathrm{P}<0.05)$. 
TABLE 1

Least squares means $( \pm \mathrm{SE}$ ) for fattening performance traits of fat-tailed Awassi, Morkaraman and Tushin lambs

\begin{tabular}{|c|c|c|c|c|}
\hline Production trait & $\mathrm{N}$ & $\begin{array}{c}\text { Initial weight } \mathrm{kg} \\
\text { mean } \pm \mathrm{SE}\end{array}$ & $\begin{array}{c}\text { Final weight kg } \\
\text { mean } \pm \mathrm{SE}\end{array}$ & $\begin{array}{c}\text { Daily weight gain } \mathrm{kg} \\
\text { mean } \pm \mathrm{SE}\end{array}$ \\
\hline Breed & & *** & **: & $*$ \\
\hline Awassi & 94 & $18.63 \pm 0.63^{\mathrm{b}}$ & $29.50 \pm 0.65^{\mathrm{b}}$ & $0.155 \pm 0.005^{\mathrm{ab}}$ \\
\hline Morkaraman & 52 & $21.95 \pm 0.74^{a}$ & $34.00 \pm 0.76^{\circ}$ & $0.172 \pm 0.006^{u}$ \\
\hline Tushin & 12 & $18.69 \pm 1.42^{1}$ & $29.07 \pm 1.47^{b}$ & $0.148 \pm 0.011^{\mathrm{b}}$ \\
\hline Sex & & $* *$ & $* *$ & $* *$ \\
\hline Male & 79 & $20.79 \pm 0.75$ & $32.55 \pm 0.78$ & $0.168 \pm 0.006$ \\
\hline Female & 79 & $18.72 \pm 0.70$ & $29.16 \pm 0.73$ & $0.149 \pm 0.006$ \\
\hline Type of birth & & *** & $* *$ & NS \\
\hline Single & 130 & $22.34 \pm 0.60$ & $33.08 \pm 0.62$ & $0.154 \pm 0.005$ \\
\hline Twin & 28 & $17.17 \pm 0.96$ & $28.63 \pm 1.00$ & $0.164 \pm 0.008$ \\
\hline
\end{tabular}

NS $=\mathrm{P}>0.05, *=\mathrm{P}<0.05, * * * \mathrm{P}<0.01$

a.h means in rows with different superscripts are significantly different at $\mathrm{P}<0.05$ or $\mathrm{P}<0.01$

The results obtained from this study on daily weight gain for $\mathrm{A}, \mathrm{M}$ and $\mathrm{T}$ lambs are in agreement with results of Buyukburc et al. (1983) of $166 \mathrm{~g}$ for Akkaraman lambs subjected to semi-intensive feeding on pasture, and Elicin et al. (1989c) of $169 \mathrm{~g}$ for Tushin male lams fed $500 \mathrm{~g}$ concentrate per head per day and grazed on pasture. The amount of concentrate consumed in addition to grazing on pasture on dry matter basis per kilogram of body weight gain averaged $2.5 \mathrm{~kg}$ for A, $2.3 \mathrm{~kg}$ for $\mathrm{M}$ and $2.7 \mathrm{~kg}$ for $\Upsilon$ lambs, respectively.

The sex of the lamb had a highly significant $(\mathrm{P}<0.01)$ effect on daily weight gain. Male lambs were heavier $(\mathrm{P}<0.01)$ than female lambs. They also had faster growth than females on pasture. Such differences have been well documented by a number of other investigators (Mavrogenis, 1996; Analla et al., 1998; Dolaksaribu et al., 2000; Macit et al., 2001). The effect of type of birth on daily weight gain was not significant on pasture $(\mathrm{P}>0.05)$. The data obtained from this study on daily weight gain is in agreement with result of Macit et al. (2001).

\section{Slaughter characteristics}

Slaughter weights of lambs were not affected by the breed of lambs (Table 2). The cold carcass weight for $T$ lambs was significantly $(P<0.05)$ lighter than that of $M$ lambs. Similarly, $T$ and $A$ lambs had lower hot dressing percentage including tail fat than that of $\mathrm{M}$ lambs. $\mathrm{T}$ lambs had significantly lower $(\mathrm{P}<0.05)$ liver weight than that of $\mathrm{M}$ lambs. The dressing percentages obtained in this study for $\mathrm{A}, \mathrm{M}$ and $\mathrm{T}$ 
TABLE 2

Least squares means ( $\pm \mathrm{SE}$ ) for weight of slaughter and non-carcass components from three fat-tailed sheep breeds in Turkey

\begin{tabular}{|c|c|c|c|c|}
\hline Slaughter trait & $\begin{array}{c}\text { Awassi } \\
n=5 \\
\text { mean } \pm S E\end{array}$ & $\begin{array}{c}\text { Morkaraman } \\
n=5 \\
\text { mean } \pm \mathrm{SE}\end{array}$ & $\begin{array}{c}\text { Tushin } \\
n=4 \\
\text { mean } \pm S E\end{array}$ & $\mathrm{P}$ \\
\hline Slaughter wcight, $\mathrm{kg}$ & $31.40 \pm 1.31$ & $33.30 \pm 1.31$ & $30.75 \pm 1.46$ & NS \\
\hline Hol carcass weight, $\mathrm{kg}$ & $16.04 \pm 0.51^{b}$ & $17.76 \pm 0.51^{4}$ & $15.05 \pm 0.57^{\mathrm{b}}$ & $*$ \\
\hline Cold carcass weight, $\mathrm{kg}$ & $15.72 \pm 0.51^{\mathrm{sb}}$ & $17.30 \pm 0.51^{4}$ & $14.60 \pm 0.57^{\mathrm{b}}$ & $*$ \\
\hline $\begin{array}{l}\text { Hot dressing percentage, } \% \\
\text { Weight of; }\end{array}$ & $51.45 \pm 1.92$ & $53.46 \pm 1.92$ & $49.09 \pm 2.15$ & NS \\
\hline Head, $\mathrm{kg}$ & $1.53 \pm 0.13$ & $1.44 \pm 0.13$ & $1.21 \pm 0.14$ & NS \\
\hline 4 foot, $\mathrm{kg}$ & $0.77 \pm 0.03^{3}$ & $0.73 \pm 0.03^{\mathrm{ab}}$ & $0.65 \pm 0.03^{b}$ & $*$ \\
\hline Hide, $\mathrm{kg}$ & $2.16 \pm 0.14$ & $1.86 \pm 0.14$ & $1.97 \pm 0.16$ & NS \\
\hline Lungs, $g$ & $395.40 \pm 25.38$ & $433.40 \pm 25.38$ & $400.00 \pm 28.38$ & NS \\
\hline Liver, g & $544.60 \pm 26.37^{\mathrm{st}}$ & $604.60 \pm 26.27^{4}$ & $510.00 \pm 29.37^{\mathrm{b}}$ & $*$ \\
\hline Heianl, g & $176.60 \pm 11.83$ & $157.40 \pm 11.83$ & $160.00 \pm 13.23$ & NS \\
\hline Spleen, $g$ & $110.60 \pm 17.29$ & $144.00 \pm 17.29$ & $100.75 \pm 19.33$ & NS \\
\hline Testis, $\mathrm{g}$ & $126.60 \pm 35.75$ & $169.20 \pm 35.75$ & $176.75 \pm 39.98$ & NS \\
\hline
\end{tabular}

$\mathrm{NS}=\mathrm{P}>0.05, *=\mathrm{P}<0.05, * *=\mathrm{P}<0.01$

a.b means in rows with different superscripts are significantly different at $\mathrm{P}<0.05$ or $\mathrm{P}<0.01$

lambs are similar to findings of Okuyan (1976) and Akcaptnar (1981) who found a range in values from 49.60 to $53.20 \%$ for fat-tailed Akkaraman lambs, and Bicer et al. (1995) who reported a dressing percentage of $48.7 \%$ for Awassi male lambs. Aksoy (1994) indicated that cold dressing percentage in Morkaraman male lambs slaughtered at $40 \mathrm{~kg}$ liveweight was $50 \%$. Also, the hot and cold dressing percentages in Tushin lams slaughtered at $42.8 \mathrm{~kg}$ weight were found to be 49.5 and $48.4 \%$ by Macit et al. (1997).

\section{Carcass characteristics}

Most of the cold carcass measurements (Table 3) except for carcass length and internal length of gigot were affected by breed of lamb. M lambs had significantly higher $(\mathrm{P}<0.01)$ width of gigot and heart girth measurements than those of $\mathrm{A}$ and $\mathrm{T}$ lambs. In addition, thoracic+lumber length and depth of gigot measurements for $M$ lambs were found to be higher than those of $T$ lambs.

The average weights of wholesale cuts of carcass weight with tail fat are presented in Table 4. A lambs had significantly higher $(\mathrm{P}<0.05)$ sirloin weight, rib weight than T lambs. However, the weight of hindshank cuts of A and T lambs was significantly lower $(\mathrm{P}<0.05)$ than in $\mathrm{M}$ lambs. $\mathrm{M}$ lambs had significantly higher $(\mathrm{P}<0.05 ; \mathrm{P}<0.01)$ weight of leg, foreshank and breast, rib and hindshank cuts than 
TABLE 3

Least squares means $( \pm \mathrm{SE}$ ) for carcass measurement of various fat-tailed sheep breeds

\begin{tabular}{llllc} 
Carcass measurement & $\begin{array}{c}\text { Awassi } \\
\mathrm{n}=5 \\
\text { mean } \pm \mathrm{SE}\end{array}$ & $\begin{array}{c}\text { Morkaraman } \\
\mathrm{n}=5 \\
\text { mean } \pm \mathrm{SE}\end{array}$ & $\begin{array}{c}\text { Tushin } \\
\mathrm{n}=4 \\
\text { mean } \pm \mathrm{SE}\end{array}$ & $\mathrm{P}$ \\
\hline Carcass length, cm & $47.10 \pm 1.32$ & $48.90 \pm 1.32$ & $44.38 \pm 1.47$ & $\mathrm{NS}$ \\
Thoracictlumber length, cm & $31.50 \pm 0.91^{\mathrm{ib}}$ & $34.20 \pm 0.91^{\mathrm{a}}$ & $29.88 \pm 1.02^{\mathrm{b}}$ & $*$ \\
Internal length of gigot. cm & $25.10 \pm 0.68$ & $25.70 \pm 0.68$ & $24.75 \pm 0.77$ & $\mathrm{NS}$ \\
Width of gigot, cm & $20.30 \pm 0.35^{\mathrm{b}}$ & $22.10 \pm 0.35^{\mathrm{a}}$ & $20.13 \pm 0.39^{\mathrm{b}}$ & $* *$ \\
Depth of gigot, cm & $16.70 \pm 0.57^{\mathrm{bh}}$ & $17.80 \pm 0.57^{\mathrm{a}}$ & $15.25 \pm 0.64^{\mathrm{b}}$ & $*$ \\
Heart girth, $\mathrm{cm}$ & $67.50 \pm 0.98^{\mathrm{b}}$ & $72.00 \pm 0.98^{*}$ & $64.75 \pm 1.09^{\mathrm{b}}$ & $* *$ \\
\hline
\end{tabular}

$\mathrm{NS}=\mathrm{P}>0.05, *=\mathrm{P}<0.05, * *=\mathrm{P}<0.0 \mathrm{I}$

a.b means with different superscripts are significantly different at $\mathrm{P}<0.05$ or $\mathrm{P}<0.01$

TABLE 4

Least squares means $( \pm S E)$ for weight of wholesale cuts from fat-tailed sheep breeds

\begin{tabular}{|c|c|c|c|c|}
\hline Wholesale cuts of carcass & $\begin{array}{c}\text { Awassi } \\
n=5 \\
\text { mean } \pm S E\end{array}$ & $\begin{array}{l}\text { Morkaraman } \\
\qquad \mathrm{n}=5 \\
\text { mean } \pm \mathrm{SE}\end{array}$ & $\begin{array}{c}\text { Tushin } \\
n=4 \\
\text { mean } \pm S E\end{array}$ & $\mathrm{P}$ \\
\hline Cold carcass weight, $\mathrm{kg}$ & $15.72 \pm 0.50^{\mathrm{b}}$ & $17.38 \pm 0.50^{\mathrm{a}}$ & $14.63 \pm 0.56^{\mathrm{h}}$ & $* *$ \\
\hline \multicolumn{5}{|l|}{ Weight of: } \\
\hline neck, $\mathrm{kg}$ & $0.70 \pm 0.05$ & $0.77 \pm 0.05$ & $0.65 \pm 0.05$ & NS \\
\hline shoulder, $\mathrm{kg}$ & $2.36 \pm 0.12$ & $2.64 \pm 0.12$ & $2.31 \pm 0.13$ & NS \\
\hline forcshank and breast, $\mathrm{kg}$ & $2.10 \pm 0.10^{\mathrm{ab}}$ & $2.36 \pm 0.10^{\circ}$ & $1.91 \pm 0.11^{\mathrm{b}}$ & $*$ \\
\hline loin, $\mathrm{kg}$ & $2.12 \pm 0.09$ & $2.12 \pm 0.09$ & $2.05 \pm 0.10$ & NS \\
\hline sirloin, $\mathrm{kg}$ & $0.89 \pm 0.04$ & $0.8 \mathbf{i} \pm 0.04^{\mathrm{ib}}$ & $0.74 \pm 0.04^{h}$ & $*$ \\
\hline leg, $\mathrm{kg}$ & $3.16 \pm 0.16^{\mathrm{ab}}$ & $3.67 \pm 0.16^{\mathrm{a}}$ & $2.94 \pm 0.18^{\mathrm{h}}$ & $*$ \\
\hline rib, $\mathrm{kg}$ & $1.18 \pm 0.06^{4}$ & $1.25 \pm 0.06^{\mathrm{a}}$ & $0.91 \pm 0.07^{b}$ & $* *$ \\
\hline flank, kg & $0.55 \pm 0.04$ & $0.56 \pm 0.04$ & $0.49 \pm 0.04$ & NS \\
\hline hindshank, $\mathrm{kg}$ & $0.51 \pm 0.05^{\mathrm{b}}$ & $0.69 \pm 0.05^{a}$ & $0.47 \pm 0.05^{\mathrm{h}}$ & * \\
\hline tail, kg & $1.99 \pm 0.07$ & $2.22 \pm 0.07$ & $2.04 \pm 0.08$ & NS \\
\hline kidney, g & $78.00 \pm 10.79$ & $82.80 \pm 10.79$ & $92.50 \pm 12.07$ & NS \\
\hline kidncy lat, $\mathrm{g}$ & $21.20 \pm 2.25^{\text {:th }}$ & $24.80 \pm 2.25^{\circ}$ & $15.00 \pm 2.5 \mathrm{I}^{\mathrm{b}}$ & * \\
\hline pelvic fat, $g$ & $24.40 \pm 5.01$ & $17.80 \pm 5.01$ & $18.50 \pm 5.61$ & NS \\
\hline M. Longissimus dorsi area, $\mathrm{cm}^{2}$ & $11.94 \pm 1.08$ & $12.94 \pm 1.08$ & $10.25 \pm 1.20$ & NS \\
\hline Fal thickness over LD, mm & $1.70 \pm 0.25$ & $1.90 \pm 0.25$ & $1.50 \pm 0.28$ & NS \\
\hline
\end{tabular}

$\mathrm{NS}=\mathrm{P}>0.05, *=\mathrm{P}<0.05, * *=\mathrm{P}<0.01$

u.b means in rows with different superscripts are signilicantly different at $\mathrm{P}<0.05$ or $\mathrm{P}<0.01$ 
$T$ lambs. The other differences among lamb breeds for the avcrage weight of carcass cuts were not significant. Significant differences among indigenous breeds reared in Turkey in terms of weights of wholesale cuts were reported by Geliyi and Ilaslan (1984), Aksoy (1994) and Macit et al. (1997).

The LD area and the average fat thickness over LD muscle indicated no significant differences among breeds (Table 4). The LD area of $M$ lambs was larger than those of $A$ and $T$ lambs. This may be expected because the slaughter weight of $M$ lambs was higher than that of $\mathrm{A}$ and $\mathrm{T}$ lambs. The mean values of fat thickness over LD area for M, A and T lambs were lower than those reported by Macit et al. (1997) for Tushin male lambs slaughtered at $42.8 \mathrm{~kg}$ and Biçer et al. (1995) for Awassi male lambs slaughtered at $40 \mathrm{~kg}$. Also, Bayındır (1980) suggested that LD area and fat thickness over LD was significantly and positively correlated with slaughter weight, and it increased as slaughter weight increased. In addition, the proportion of fat in the carcass increases while that of bone and lean decreases with increasing slaughter weight. In terms of consumer and producer preferences, the optimum slaughter weight for native fat-tailed breeds under grazing with concentrate was reported to be $38-40 \mathrm{~kg}$ by Elicin et al. $(1989 \mathrm{c})$.

The average weight of wholesales cuts as proportions of cold carcass weight including tail fat are presented in Table 5. A lambs had a significantly higher $(\mathrm{P}<0.05)$ proportion of sirloin than $\mathrm{M}$ lambs. In addition, the proportion of loin cuts of T lambs

TABLE 5 Least squares means $( \pm S E)$ for proportion of wholesale cuts including tail fat from fat-tailed shecp breeds

\begin{tabular}{|c|c|c|c|c|}
\hline & $\begin{array}{c}\text { Awassi } \\
n=5 \\
\text { mean } \pm S E\end{array}$ & $\begin{array}{c}\text { Morkaraman } \\
n=5 \\
\text { mean } \pm \mathrm{SE}\end{array}$ & $\begin{array}{c}\text { Tushin } \\
n=4 \\
\text { mean } \pm S E\end{array}$ & $\mathrm{P}$ \\
\hline Cold carcass weight, $\mathrm{kg}$ & $15.72 \pm 0.50^{\mathrm{b}}$ & $17.38 \pm 0.50^{n}$ & $14.63 \pm 0.47^{1}$ & $* *$ \\
\hline \multicolumn{5}{|l|}{ Proportion of cuts, $\%$} \\
\hline neck & $4.47 \pm 0.27$ & $4.43 \pm 0.27$ & $4.39 \pm 0.31$ & NS \\
\hline shoulkler & $15.03 \pm 0.43$ & $15.16 \pm 0.43$ & $15.72 \pm 0.48$ & NS \\
\hline foreshank and breast & $13.35 \pm 0.53$ & $13.63 \pm 0.53$ & $12.99 \pm 0.59$ & NS \\
\hline loin & $13.48 \pm 0.46^{\text {il }}$ & $12.20 \pm 0.46^{\mathrm{b}}$ & $14.07 \pm 0.5 \mathrm{l}^{\mathrm{a}}$ & $*$ \\
\hline sirloin & $5.64 \pm 0.2]^{i}$ & $4.66 \pm 0.21^{h}$ & $5.09 \pm 0.23^{\text {ilt }}$ & $*$ \\
\hline leg & $20.05 \pm 0.61$ & $21.11 \pm 0.61$ & $20.02 \pm 0.69$ & NS \\
\hline rib & $7.51 \pm 0.42^{4}$ & $7.22 \pm 0.42^{\mathrm{a}}$ & $6.20 \pm 0.46^{b}$ & $*$ \\
\hline llank & $3.49 \pm 0.20$ & $3.22 \pm 0.20$ & $3.35 \pm 0.23$ & NS \\
\hline hindshank & $3.24 \pm 0.26$ & $3.96 \pm 0.26$ & $3.20 \pm 0.29$ & NS \\
\hline tail fat & $12.65 \pm 0.34^{b}$ & $12.77 \pm 0.34^{11}$ & $13.98 \pm 0.38^{4}$ & * \\
\hline kidney & $0.13 \pm 0.003$ & $0.13 \pm 0.003$ & $0.14 \pm 0.004$ & NS \\
\hline
\end{tabular}

NS $=\mathrm{P}>0.05, *=\mathrm{P}<0.05, * *=\mathrm{P}<0.01$

ut. means in rows with different superscripts are significantly different at $P<0.05$ or $P<0.01$ 
was significantly higher $(\mathrm{P}<0.05)$ than in $\mathrm{M}$ lambs. The other differences among lamb breeds for proportional weight of carcass cuts were not significant.

In general, the results obtained from this study revealed that $M$ lambs excelled over $\mathrm{A}$ and $\mathrm{T}$ lambs reared in eastern Turkey in daily weight gain, concentrate feed consumption in addition to pasture per liveweight gain and the proportion of hindshank cuts in carcass characteristics. Male lambs were superior to female lambs with respect to daily weight gain and the amount of concentrate consumption in addition to grazing on pasture per kilogram weight gain.

\section{CONCLUSIONS}

As a result, it is recommended that either $\mathrm{A}, \mathrm{M}$ and $\mathrm{T}$ male and female lambs weaned at 2.5 months of age in eastern Turkey should be fed with $450 \mathrm{~g}$ concentrate per head per day on pasture for 3 to 3.5 months of the grazing season, or lambs should be supplemented with more than $450 \mathrm{~g}$ concentrate on pasture because native fat-tailed Turkish breeds supplemented with $450 \mathrm{~g}$ concentrate on pasture did not give carcasses with an adequate commercial weight at the end of the 70-day of fattening period.

\section{REFERENCES}

Akcaptnar H., 1981. Comparison of fattening performance and carcass characteristics of Dağlç, Akkaraman and Kıvtrcık lambs at different slaughter weights. Ankara University, College of Agriculture, Yearbook 28, 112-129

Aksoy A.R, 1994. Fattening performance, slaughter and carcass characteristics of Morkaraman and Tushin male lambs at different slaughter weight. Kafkas University, Kars College of Veterinary, Ycarbook 42, 15-23

Analla M., Montilla J. M., Serradilla J.M., 1998. Analyses of lamb weight and ewe litter size in various lines of Spanish Merino sheep. Small Ruminant Res. 29, 255-259.

Anonymous, 1973. Uniform retail meat identity standards. A program for the retail meat trade by the industry wide cooperative meat identification standards committee. National Livestock and Meat Board, Chicago

Anonymous, 1997. Agricultural Structure (Production, Price, Value). State Institute of Statistics Prime Ministry Republic of Turkey, Ankara

Bayındır S., 1980. Growth, fattening and carcass characteristics of Morkaraman, Merino and their crosses with relationships among them. Unpublished Thesis for Associate Professorship, Atatürk University, College of Agriculture, Erzurum (Turkey)

Bicer O., Güney O., Pekel E., 1995. Effect of slaughter weight on carcass characteristics of Awassi male lambs. J. Appl. Anim. Res. 8, 85-90

Bicer O., Pekel E., Güney O., 1992. Effects of docking on growth performance and carcass characteristics of fat-tailed Awassi male lambs. Small Ruminant Res. 8, 353-357 
Buyukburc U., Ilaslan M. Cangir S., 1983. A study on comparison of fattening performances of lambs subjected to semi intensive feeding on artificial and natural pastures in village and fed on concentrate to be ad-libitum. Publication of Meadow-Pasture and Animal Science Research Institute, Number 81, Ankara (Turkey)

Doloksaribu M., Gatenby R.M., Subandriyo, Bradford G.E., 2000. Comparison of Sumalra sheep and hair sheep crossbreds. III. Reproductive performance of $F_{2}$ ewes and weights of lambs. Smalt Ruminant. Res. 38, 115-121

Duncan D. B., 1955. Multiple range and multiple F tests. Biometrics 11, 1-42

Elicin A., Askın Y., Cengiz F., Ertugrul M., Artk Z., 1989a. A study on fattening performance and carcass characteristics of Akkaraman and Ile de France $x$ Akkaraman $\left(F_{1}\right)$ crossbred male lambs. Ankara University, Publication of Agriculture Faculty, Number 1124, Scientific Research and Studies. 614, Ankara (Turkey)

Elicin A., Aşkın Y., Cengiz F., Ertuğru! M., Delłal G., 1989b. A study on fattening performance and carcass characteristics of Karayaka and Border Leicester $x$ Karayaka $\left(F_{1}\right)$ crossbred male lambs. Ankara University, Publication of Agriculture Faculty, Number 1123, Scientific Research and Studies. 613, Ankara (Turkey)

Elicin A., Geliyi C., Ertuğrul M., Cengiz. F., Ilaslan M., Askın Y,, 1989c. Fattening performance and carcass characteristics of Tushin lambs supported with different amount of concentrates on pasture. Ankara University, College of Agriculture, Yearbook. 40,1-2

Geliyi C., Ilaslan M., 1984. Studies on fattening performance and carcass characteristics of Tushin, Merino, Tushin $x$ Merino crosbred male lambs fed on diets containing different ratios of roughage and concentrate. Il. Slaughter and carcass characteristics. Publication of Kars Research Institute, Number 12, Kars, pp. 15

Guney O., Bicer O., 1986. Fattening performance and carcass characteristics of Aw x Aw, Ile de France $x$ Aw $\left(F_{1}\right)$ and Chios $x$ Aw ( $\left.B_{1}\right)$ first back cross ram lambs. World Rev. Anim. Prod. 22, 63 67

Kempster A.J., Cuthbertson A., Harrington G., 1982. Carcass Evaluation in Livestock Breeding, Production and Marketing. Granada Publishing Ltd., Frogmore, St. Albans, Herts, AL2 2NF/ ENG, 307

Macit M., Karaoglu M., Esenbuga N., Kopuzlu S., Daytoglu H., 2001. Growth performance of purebred Awassi, Morkaraman and Tushin lambs and their crosses under semi-intensive management in Turkey. Small Ruminant. Res. 20, 59-65

Macit M., Karaoglu M., Yaprak M., Kopuzlu S., 1997. Determination of the fattening performance, slaughter and carcass characteristics of Tushin lambs under intensive farm conditions. Atatürk Universty, College of Agriculture Erzurum, Yearbook 28, 454-463

Macit M., Yaprak M., Aksoy A., 1996. A study on fattening pertormance, slaughter and carcass characteristics of Morkaraman male lambs under intensive farm condilions. Yüzüncü Yul University. College of Agriculture Van, Yearbook 6 (2), $61-74$

Mavrogenis A. P., 1996. Environmental and genetic factors influencing milk and growth trats of Awatssi sheep in Cyprus. Heterosis and maternal effects. Small Ruminant Res. 20, 59-65

Okuyan M.R., 1976. Studies on determination of amount of need for daily hay consumption of lambs subjected to intensive feeding. Ankara University, Publication of Agriculture Faculty, Number 629, Scientific Research and Studies. 372

SAS, 1985. SAS Introductory Guide. 3rd Edition. Cary, NC 


\section{STRESZCZENIE}

\section{Wzrost i charakterystyka tusz jagniąt tlusto-ogoniastych ras Awassi, Morkaraman i Tushin utrzymywanych na pastwisku i dokarmianych paszą treściwą}

Badano wzrost $(n=158)$ oraz przeprowadzono ocenę tusz pięciu jagniąt Awassi (A), pięciu Morkaraman (M) i czterech Tushin (T), odsadzonych w wieku 2,5 miesiąca. Jagnięta utrzymywane na pastwisku przez 70 dni dokarmiano mieszanką pasz treściwych, po czym ubito wybrane z grup rasowych zwierzęta. Najwyższe przyrosty miały jagnięta $M$ i najlepiej wykorzystywały paszę treściwą na przyrost masy ciała. Wpływ rasy i płci jagniąt na dzienne przyrosty był odpowiednio istotny $(\mathrm{P}<0,05)$ lub wysoce istotny $(\mathrm{P}<0,01)$. Tryczki miały lepsze przyrosty niż jarliczki. Ciężar tuszy ciepłej oraz pręgi tylnej jagniąt $\mathrm{M}$ był większy niż jagniąt pozostałych ras. Podobnie wydajność rzeźna ciepła oraz powierzchnia oka polędwicy jagniąt $\mathrm{M}$ były większe niż jagniąt $\mathrm{A}$ i $\mathrm{T}$. Ciężar większości wyrębów wartościowych był istotnie $(\mathrm{P}<0.05 ; \mathrm{P}<0.01)$ zależny od rasy.

Na podstawie otrzymanych wyników autorzy zalecają, aby jagnięta Awassi, Morkaraman i Tushin, obydwóch płci, odsadzone w wieku 2,5 miesiąca i wypasane na pastwisku w zachodniej Turcji, przez 3 do 3,5 miesiąca otrzymywały dodatek paszy treściwej w ilości $450 \mathrm{~g} / \mathrm{sztuka/dzień,}$ a nawet większy. Jagnięta ras thusto-ogoniastych utrzymywane na pastwisku i dokarmiane paszą treściwą w ilości $450 \mathrm{~g}$ nie produkują bowiem tusz o pożądanym handlowym ciężarze w ciągu 70 -cio dniowego tuczu. 